DOI: 10.1515/ausp-2016-0002

\title{
Discourses of the I: The Panic of Identity in Edward Albee's Me, Myself and I
}

\author{
Boróka PROHÁSZKA-RÁD \\ Sapientia Hungarian University of Transylvania (Miercurea Ciuc, Romania) \\ Department of Humanities \\ boroprohaszka@yahoo.com
}

\begin{abstract}
Hello, there! My name is OTTO. [...] I want to make trouble because I want to make things even more complicated than they are around here, and then maybe I can get out of this whole mess - this family and everything. Let's see: my name is OTTO. I have an identical twin brother. I'm trying to get rid of him, rid of all of them - but it's not easy: you know how twins are; well, maybe you don't" - OTTO, one of the identical twin brothers (both named Otto) of Edward Albee's Me, Myself and I opens the play addressing the audience. Albee's wit and sharp irony dominate the play, managing to "engage, to upset, to trouble" audiences and readers. In my paper I analyze the methods Albee employs in transforming the stage into a meta- and intertextual "space" subverting and undermining any belief in identity and language as fixed, stable and functional "entities."
\end{abstract}

Keywords: Albee, Me, Myself and I, subjectivity, metatheater.

Asked whether he would elaborate on the theme of identical twins in his plays (The American Dream, Me, Myself and I), Edward Albee answered that it was a "powerful dramatic device" but "not worth a PhD dissertation" (After Show Discussion 2008a). Me, Myself and I, that premiered in January 2008 at Princeton, McCarter Theatre Center while Albee was the first recipient of the Princeton University/McCarter Theatre Playwriting Fellowship, builds on this "powerful dramatic device," and becomes a representation of the "primitive horror of [and fascination with] the Same" (Girard's phrase 1978). While in The American Dream through the mutilation of one twin the other turns into a monstrous, uncanny double, an empty shape invested with the status of a symbol, the simulacrum of an invalidated myth, in the 2008 play the rupture is induced voluntarily by one of the twins, OTTO. "Gemini," Jean Baudrillard states, "possess a specific property, a particular and sacred fascination of the Two, of what is two together, and never was one" (1994, 97). Through breaking the bond of twins, OTTO embarks and pushes his brother, lowercase otto, into an endless process of 
multiplication, simulation, that destabilizes any subject position and the very process of signification.

Caught in the double trap of being terrified and at the same time enchanted by simulation, being unable to resist the magic and the horror of the simulacrum, Mother finds it perfectly logical to name both her sons Otto - a palindrome name - being later frustrated and confused by her own doing. OTTO cannot resist breaking away from the situation, and from his identical twin, just to immediately find a new, a "true identical twin brother" in his own mirror image, transforming thus both himself and lowercase otto into duplicates of a never-existed original, depthless models without a source. He creates an epistemic and ontological gap, he indulges in ambiguity and uncertainty; he uses the paradoxical logic of the game set up by Mother in the first place to refashion the playing field upon which their subjectivity has been inscribed and to reorganize the power system that circumscribes the positions they are supposed to occupy. He farther destabilizes the "delicate balance," the uncanny symmetry that Mother has created - by giving birth to identical twins and naming them the same - subverting the binary system of signification, of sign and referent.

The motif of the doppelganger and doubling has been a recurring theme in literature from folklore to works by Shakespeare, Poe, Dickens, Wilde, Borges, and many others. It often appears as the embodiment of split identity, belonging to the realm of the carnivalesque, the monstrous, the supernatural, suggesting the threatening possibility of expropriation of identity. In Albee's play as well, the motif of twins and OTTO's struggle to separate himself from and "get rid" of his brother create a play that "[o]n the surface [...] is a very funny story of a pair of twin brothers and their family, but on the deeper level [it] addresses core questions of our modern society. How do we shape our identities and sense of self in a world that seems to inscribe culture upon us? In our increasingly virtual era, does the very meaning of existence change? In an age of molecular biology, how do we distinguish ourselves from our DNA?" - as Emily Mann, director, phrases it.

In his "Letter to an Audience" Albee states:

I tend to become uncooperative - and occasionally downright hostile - when people ask me what my plays "are about" [...] What is Me, Myself and I about? Oh, about two hours, including intermission. [...] A play is, after all, about everything that happens to the characters from the beginning of the play to the end and (unless the author has killed them all off by curtain) the characters' lives before the play begins and after it ends. This means, as I see it, that a play is fully described (or explained) by the experience of seeing it. (2008b, 3) 
As we now do not have the possibility to "see," that is experience the entire play in its whole length of about two hours (including intermission), I will try to sum it up - though in the case of Me, Myself and I, without a traditional plot and its constant destabilization of the process of theatrical representation, of verbal signification, it will be quite a challenge.

We learn that twenty-eight years ago Mother gave birth to identical twin boys upon which their father left. Doctor has subsequently moved in as he "read Mother's vibes" and understood that he was needed. We step into the family's life in medias res, with OTTO announcing his Mother that, on the one hand, he is going to become Chinese as the future is in the East and he "wants in on it" and, on the other, that his twin, otto, does not exist any longer. This announcement then propels the whole play into the realm of ontological and epistemological questioning. Mother constantly asks "Who are you? Which one are you? Are you the one who loves me?", otto falls into an acute crisis of identity being denied his existence by his brother, his mother and Doctor, as well as by Maureen, his girlfriend, who sees him, feels him, loves him, even faces the challenge of talking to Mother to convince her that otto exists, but who - being unable to tell the twins apart - sleeps with OTTO. The final scene of confrontation, when otto tries to prove his existence and regain his position in the system, when he tries to reinscribe himself into the mesmerizingly unstable discourse of the play, even after OTTO's declaration that he has been replaced by a "true" identical twin, Otto in italics, is interrupted by the appearance of the twins' father, Man, on a cart pulled by black panthers (the four-legged kind), packed with emeralds (all papier-mâché), with the banner "The happy ending," just as OTTO has suggested earlier he would. But Mother's accusations make him change his mind - flip the banner to "The former happy ending" - and leave once again.

Structurally the play is divided into two acts. Act I begins with a pre-scene with OTTO in front of the red curtain addressing the audience:

OTTO: (Out, entering from left, moving center.) Hello, there! My name is OTTO. I'm on my way to see my mother. (Indicates red curtain.) She's back there. I'm going to see her because I want to make trouble, because I want to make things even more complicated than they are around here, and then maybe I can get out of this whole mess - this family and everything. Let's see: my name is OTTO. I have an identical twin brother. I'm trying to get rid of him - so I can get rid of him, rid of all of them - but it's not easy: you know how twins are; well, maybe you don't. [...] They're so hard to get rid of - these twins! ( 2011, 5; emphasis in the original)

It ends with a post-scene, OTTO once again addressing the audience directly as the curtain closes: "I think I'm making progress - fucking everything up. 
(Imitating Mother.) 'otto my darling ... you don’t exist.' (Imitating otto.) ‘How can this be!? How can this be!?' Well ... that is a dilemma. How do we solve it? How do we figure that one out?! Hmmm! (Idea.) Well, perhaps an intermission would help" (2011, 38; emphasis and ellipsis in the original).

Act II consists of seven scenes and ends with a Conclusion - the two brothers trying to come to terms with the inescapability of their subjectivity(ies) and with their now existent third, "this new Otto:"

otto: (Almost crying.) And how are we going to deal with that [Otto]!? OTTO: (Thinks about it.) Well ... I guess we'll just have to think of ourselves as triplets. (Pause; finally they laugh, embrace.) otto: What do we do now, huh?

OTTO: (Indicates the curtain.) Well, I think the play's over. Let's go join the curtain call. (2011, 77; emphasis and ellipsis in the original)

As it becomes obvious from even such a brief - and necessarily inadequate - summary, Me, Myself and I is a play which indulges in its own genre, its own medium - language and visual representation, and in its central theme, subjectivity and the relation between reality and the imagination, the reality of and in a literary work, deconstructing and destabilizing them, playing out one against the other, and showcasing their instability and ambiguity. In his "Letter" Albee warns his audiences: "My plays [...] can be enjoyed to their full, unless you bring to the theatre with you the baggage of predetermination - 'a play must go like this"” (2008b, 1). However, Me, Myself, and I does display itself as a meta- and intertextual discourse that does necessitate some knowledge and understanding of theatrical conventions and literary references in order for one to disclose the subversive and the ironic (in the Hutcheonian sense) nature of the play.

The subject appears as fundamentally destabilized, in a continuous struggle to attain balance from where necessarily it will shift into uncertainty again. Julia Kristeva argues that the speaking subject is necessarily, always already split, under the constant pressure of his Freudian drives and social constraints. Though the system presupposes a unified, transcendental ego that operates only within practices that subserve the system, the active, speaking subject is capable of endless combinations of positions and elements of the system, able to create games, to play, thus positioning him/herself outside the realm that the system can grasp and describe within its own logic. For any deviation from the rules fragments the order and becomes "unreadable," it resists intelligibility (1986).

By the very fact of giving birth to identical twins Mother already subverts the system. This "malfunction" sets her on the course of becoming a subject who - as Doctor states - "strew[s] confusion in [her] path" $(2011,60)$. Naming both her sons Otto makes sense to her: "You don't see the logic of it ... identical twins, identical 
names" (2011, 22; ellipsis in the original) for "when they were old enough to know they had names, they knew they were the same person," "I would take them in my arms and make them one. They would nestle there and enfold and ... become one - be one" (2011, 23; ellipsis in the original). She turns into one of the “archetypal Albee mothers” (Lahr 2010) - like Martha in Who's Afraid of Virginia Woolf?, Mommy in The American Dream, A in Three Tall Women or Woman in The Play about the Baby), who by the palindromic name acknowledges her sons' identical physical reality but "outrageously denies them their individual interiors" (Lahr 2010).

In this sense OTTO’s “declaration of independence” (Lahr 2010) reads as an attempt of finding a way out of this labyrinth of shifting meanings. He becomes a good "dessembler" $(2011,68)$ as he puts it, deconstructing what would read as an allegorical story of inner struggle externalized in the figures of the twins embodying two sides of the coin, that is two different personae of one and the same personality and - as Ben Brantley argues - "about the need of all children to divorce themselves from the collective identity of family" (2010). He dissembles further markers of his subjectivity as well: nationality, language, and the fundamental element of his existence, that of being a character in a play. ${ }^{1}$ Thus function his declarative statements that he is tired of being an "occidental" and - given that "the future is in the East" - he is leaving and he is going to be Chinese $(2011,13)$, that he has a new brother and "the old one is gone. He doesn't exist. Poof! Gone! Just like that!” $(2011,15)$, which set the play in motion and generate the existential crisis that has already been lurking in the air from the twins' birth. Within the "reality of the play" as Albee calls it, these utterances appear as "performatives" in the sense that J. L. Austin ascribes to them. Austin states that given that not all utterances "state" a fact or "describe" a state, and neither are all of them verifiable as true or false, we should/can differentiate a quite versatile group that he calls "performatives" in whose case "the uttering of the sentence is, or is part of, the doing of an action" $(2000,290)$, deriving their name from "perform," the usual verb with the noun "action:" "it indicates that the issuing of the utterance is the performing of an action" (2000, 291). Accordingly, OTTO's declaration nullifies otto's existence, he is erased from the discourse. Of course, Austin also states that "a performative utterance will [...] be in a peculiar way hallow or void if said by an actor on the stage, or if introduced in a poem or spoken in soliloquy" as "[l]anguage in such circumstances is in special ways - intelligibly - used not seriously, but in ways parasitic upon its normal use” (2000, 298), which leads us to a discussion

1 A similar decomposition of subjectivity markers opens Albee's Occupant where Louise Nevelson challenges every word of Man's introductory phrase: "Ladies and Gentlemen ... the great American sculptor ... Louise Nevelson" (Albee 2005, 626; ellipsis in the original), as I show in "The Dead Tell No Tales!? Edward Albee's Occupant" published in HJEAS 2012. 
of two other fundamentally ambiguity-leaden aspects of Me, Myself and I: its language and the issue of reality of a/in a play.

In The Death of Character: Perspectives on Theatre after Modernism Elinor Fuchs argues that in contemporary drama "character has lost its preeminence with its wholeness, it has dissolved into a flux of performance elements" (1996, 173). Neither do these works preoccupy themselves with the duality of illusion and/vs. reality as "[t]he question has disappeared with the new perception that all fixed reality is a fiction" (Fuchs 1996, 175). Me, Myself and I questions not only any stable identity, but the stability of meaning, the functionality of the process/any process of signification, and the possibilities of the genre to convey all this instability - itself being a sign-system with set conventions and a heritage of over two thousand years. As Fuchs states "'character' as a term of dramatic art can never be independent of contemporary constructions of subjectivity" (1996, 8). Understanding subjectivity then as a process through which one becomes an active/speaking subject inscribed by culture through/in language, Albee's preoccupation with language and theatre becomes a means of not only epistemological, but ontological, philosophical and critical questioning.

Me, Myself and I builds on the hallmark Albee wordplay, wit and humor, where the most fundamental questions of identity turn into verbal acrobatics. Every word, phrase and expression is dissected, analyzed and its referents multiplied. This is a game that Mother has initiated and that she and her "omniscient" Doctor partner play at mastery level, so no wonder that somebody uninitiated and unaccustomed to their game (like Maureen), asks: "Is this English she's speaking?" $(2011,56)$. Even such banalities as the expression "ta-ta" occasion verbal duels:

OTTO: [...] TA!

Dr.: (To exiting OTTO.) The expression is not "Ta!", the expression is "Ta-ta!" Mother: What?

Dr.: (To Mother.) Ta-ta! The expression "goodbye" is Ta-ta.

Mother: Goodbye? Where are you going?

Dr.: (Shakes his head.) Forget it. [...]

Mother: [...] And then he said "Ta!" or something. (To Dr.) What does that mean?

Dr.: What does what mean?

Mother: Ta! What does ta mean?

Dr.: We've been through this! The expression is not "ta!" The expression is "Ta-ta!"

Mother: ("Remind me.") And what does that mean?

Dr.: It means goodbye.

Mother: (Accusatory.) You see!? I said you were going somewhere!

Dr.: (Getting out of bed.) You're not nice. (2011, 15-17) 
The crisis of identity also manifests itself as the breakdown of communication. Lowercase otto's first sense of terror with reference to loss of identity arises from his brother pretending not to hear him: "otto: I'll see him coming and I'll say hello, and it's as if he was deaf: he doesn't hear me. It's been going on for - what? - days now, and just now: 'OTTO,' I said and he just walked by me. I yelled: 'Hey, OTTO!' ... and ... nothing. [...] it was [...] as if I wasn't there, as if I ... didn't exist" (2011, 32; emphasis and ellipsis in the original). Later, he uses talk, language to try to prove his existence (also asking Maureen to talk to his Mother and convince her that he still exists):

otto: I don't exist.

Mother: Yes; I mean no. No; you don’t exist.

Dr.: You've been replaced.

otto: (Guffaw.) I don't exist!

Mother: I'm sorry; yes.

otto: Mother, who are you talking to?

Mother: Why ... you, of course. My baby boy; my otto.

otto: (To Dr.) And you. Who are you talking to?

Dr.: To your mother, mostly. (otto raises his arm threateningly.) You! To you. You, of course.

otto: (Pause.) Then I do exist. (2011, 36; emphasis and ellipsis in the original)

However, in concordance with Austin's thesis that performatives need to be witnessed, his vanishing is considered as effected given that, as Doctor argues, it has been uttered and the utterance has been heard:

Mother: Well ... so we'll talk. That's what the girl wants to do, as I understand it ... talk. "Can we talk?" she said on the phone. "Can we meet and talk?" I would have thought she'd say "May we," but what do I know? "Can we talk? otto asked me to call you." As I said, she sounded urgent. What do you suppose it's about?

Dr.: (Feigning puzzlement.) Gee, I can't imagine. Do you think it could have anything to do with OTTO - big OTTO; loud OTTO - having decided little otto doesn't exist?

Mother: (Dismissive.) People don't decide things like that.

Dr. You heard him! You heard him say it!

Mother: Fiddlesticks!

Dr.: (Out.) And I haven't heard that one in a long while either!

Mother: What people say and what they mean don't always mesh. You know that! 
Dr. Yes, but you heard him say it! (2011, 52-53; emphasis and ellipsis in the original)

Implicitly, the limitations of theatrical representation also occupy a central position. Albee constructs a postmodern pastiche world - to use Fredric Jameson's term according to whom postmodern culture constitutes "a world in which stylistic innovation is no longer possible, all that is left is to imitate dead styles, to speak through the masks and with the voices of the styles in the imaginary museum" (quoted in Storey 2003, 150). Me, Myself and I abounds in cultural references: from T. S. Eliot's The Waste Land to the Black Panthers - though specified that here they refer to the "four-legged ones," they still evoke American history, while at the end of the play the Father appearing "driving a chariot - all the following clearly oversize and fake: papier-mâché, or whatever - pulled by four big black panthers on wheels - clearly fake" $(2011,73)$ remind one of Walt Disney cartoons but also evoke Willy Loman's fantasies of his brother Ben and his "emeralds." Dramatic genres and conventions are scrutinized, merged and played out against each other. The domestic realist tradition of American drama history is reshaped by its mixture with elements of classical tragedies and Shakespearian comedy built on mistaken identities, features of vaudeville and farce, while the minimalist set, the constant experimentation with language, self-referenciality pay homage to theatrical ancestors from O'Neill's relentless quest for new forms in drama to Pirandello, Ionesco, Tennesse Williams and, of course, Beckett, in whose honor Albee raises Doctor's bowler hat. As it becomes obvious even before the curtain raises, the play constantly breaks the fourth wall illusion, drawing attention to its own artificiality. Beyond the characters constantly addressing the audience directly, there are whole scenes delivered in soliloquy (Scene 2 and Scene 4 in Act II), they also discurse on theatrical conventions and make comments on themselves being characters in a play:

Mother: [...] (Out.) You don't see the logic of it... identical twins, identical names?

Dr.: (A general statement.) Symmetry, yes; logic, no.

Mother: I wasn't talking to you.

Dr.: Yes, I know. (Points.) To them! But you're confusing them, and a confused audience is not an attentive one, I read somewhere.

Mother: Oh? (Thinks.) King Lear is confusing.

Dr.: (Granted.) True.

Mother: And people pay attention to King Lear. Or they try to.

Dr.: They know they're supposed to. (2011, 22; emphasis in the original) 
Dr.: Where are you going?

Mother: I've got to pee.

Dr.: We're doing a scene here.

Mother: Well, vamp or something. I've got to pee.

Dr.: Yes, but...

Mother: I've been doing nothing but sitting in the damn bed ever since we started. Talk about the twins or something. I'm going. (2011, 25)

(OTTO appears at stage left proscenium, unseen by otto and Maureen. Leans; finger to lips, to silence audience. Watches.) $(2011,40)$

OTTO: [...] Ah, well; off we go. (Hears voices.) Oh, wait! Some people are coming. (Indicates off upstage right.) I think I'll stick around and snoop. In the Japanese puppet theatre - the Bunraku - there's a tradition that if the people who are manipulating the puppets wear black fishnet - while they're on stage - they're invisible. It's really magical. (Moves to stage left proscenium.) Now, in Western theatre, there's the tradition that if you lean against a proscenium just so, (Does so.) you can watch a scene and the people who are in the scene won't see you. At least I hope that's the tradition. (2011, 47; emphasis in the original)

When asked with reference to such seeming distrust of dramatic realism, Albee argued: "I think I learnt the fourth wall thing from Brecht more than anybody. I like an audience to be confronted and have the characters talk to them, and sometimes even ask them to talk back. I don't want them to be, you know, spies. I want them to participate in the reality of the play" (Goldberg 2010). Me, Myself and $I$ demands such active participation from audiences. It confronts us with the paranoia and panic of our times: is it possible that we could just vanish like so many of what Toby Zinman (2008) calls Albee's “imaginary sons, invisible sons, vanishing sons, silent sons" or in Scott Brown's terms "ghost sons" as in Who's Afraid of Virginia Woolf?, Three Tall Women, The Play about the Baby? Does our identity consist merely of elements that can/will be expropriated and that constitute constantly shifting personae? Are we mere "role-playing subjects" (Fuchs 1996, 6) in a sustained transition, trapped in the labyrinth of the evermultiplying layers of meaning? Are we similar, or rather identical with otto who struggles exasperatedly to pin down the meaning of what he is told and what he says, and thus to prove his existence, to be heard, to communicate, that is proclaim his individuality through language, words that keep exploding into multiple meanings. These characters inscribed in their own illogical though symmetrical discourse, constantly questioning and manipulating language, and of course being manipulated and modified by the very language they use and 
through which they exist, stand for what Ben Brantley has called "the ruling passion, jubilant and exasperated" of Albee (and Stoppard), whose "faithless lovers $[\ldots]$ are words:"

It is one of the livelier paradoxes of the English-speaking theater today that its two most dazzling wordsmiths are incurably suspicious of the language they ply with such flair. No other living playwrights give (and, it would seem, receive) more pleasure from the sounds, shapes and textures of their lavishly stocked vocabularies. And none is more achingly conscious of the inadequacy of how they say what they say.

This contradiction is not just an element of their style; it's the essence of it. It's what gives that distinctive, heady tension to their plays, the friction that sends the minds of receptive theatergoers into exhilarated overdrive. (Brantley 2008, 8)

\section{Works Cited}

Albee, Edward. 1963. The American Dream and The Zoo Story. New York: Plume Book.

Albee, Edward. 2005. Occupant. In The Collected Plays of Edward Albee. Vol. 3, 623-700. New York, Woodstock, London: Overlook Duckworth.

Albee, Edward. 2008a. After Show Discussion The American Dream and Sandbox. New York, Cherry Lane Theatre. March.

Albee, Edward. 2008b. "Letter to an Audience." Playbill. Me, Myself, and I.

Albee, Edward. 2011. Me, Myself, and I. New York: Dramatists Play Service.

Austin, J. L. 2000. How to Do Things with Words. In Twentieth-Century Philosophy, eds. Forrest E. Baird and Walter Kaufmann, 288-298. Upper Saddle River, New Jersey: Prentice Hall.

Baudrillard, Jean. 1994. Simulacra and Simulation. Ann Arbor: Michigan University Press.

Brantley, Ben. 2008. Albee and Stoppard: Playing on Words. In International Herald Tribune 21 Feb: 8.

Brantley, Ben. 2010. "I Know You Are, but What Am I, and Who Is He?" Review. The New York Times 12 September http://www.nytimes.com/2010/09/13/ theater/reviews/13memyself.html?_r=0 (Last accessed 15 May 2016)

Brown, Scott. 2010. A Too-Delicate Balance. Review. http://nymag.com/arts/ theater/reviews/68219/ (Last accessed 15 May 2016)

Fuchs, Elinor. 1996. The Death of Character: Perspectives on Drama after Modernism. Bloomington and Indianapolis: Indiana University Press.

Girard, René. 1978. "The Double Business Bound". Essays on Literature, Mimesis, 
and Anthropology. Baltimore: Johns Hopkins University Press.

Goldberg, Isa. 2010. Interview with Edward Albee. Financial Times 4 September http://www.ft.com/cms/s/2/9d442662-b6e9-11df-b3dd-00144feabdc0. html\#axzz2h8c14Rjk (Last accessed 15 May 2016)

Kristeva, Julia. 1986. The System and the Speaking Subject. In The Kristeva Reader, ed. Toril Moi, 24-33. Oxford: Basil Blackwell.

Lahr, John. 2010. Me and My Shadow. Edward Albee's Alternate Selves. Review. The New Yorker 27 September. http://www.newyorker.com/ magazine/2010/09/27/me-and-my-shadow-lahr (Last accessed 15 May 2016)

Mann, Emily. Emily Mann on Me, Myself, and I. https://www.mccarter.org/ Education/me-myself-i/html/1.html (Last accessed 15 May 2016)

Prohászka-Rád, Boróka. 2012. The Dead Tell No Tales!? Edward Albee’s Occupant. HJEAS vol. 18 no. 1-2 (Spring-Fall): 357-370.

Storey, John. 2003. Postmodernism and Popular Culture. In The Routledge Companion to Postmodernism, ed. Stuart Sim, 147-157. London and New York: Routledge.

Zinman, Toby. 2008. Albee's Playful Take on a Recurring Serious Theme. Review. http://articles.philly.com/2008-01-28/news/25254843_1_otto-zoo-story-albeemen (Last accessed 15 May 2016) 